\title{
STUDENTS WITH A MIGRANT BACKGROUND: POSSIBILITIES AND PROBLEMS OF THEIR INTEGRATION INTO EDUCATION SYSTEM
}

\author{
Eglẻ Stasiūnaitienè \\ Vytautas Magnus University, Lithuania \\ Rasa Nedzinskaitė-Mačiūnienė \\ Vytautas Magnus University, Lithuania \\ Gerda Mazlaveckienè \\ Vytautas Magnus University, Lithuania
}

\begin{abstract}
This paper examines the integration of students with a migrant background and the problems encountered by the teachers, who seek for their successful integration via the educational process. A qualitative approach has been chosen for the research. On the basis of a semi-structured interview $(N=12)$, it is proposed that despite the existing migrant policy, there are still urgent demands from teachers to get specific methodology of working with students from migrant backgrounds. Moreover, the school administration and teachers often have to search for optimal and individual decisions to ensure the process of integration. The most frequently used means of ensuring children's integration into the educational process include individual education plans, non-formal activities, tutoring in the Lithuanian language, as well as application of the support model for individual student(s). Finally, parent involvement into the processes of children's education and integration could be more active, yet they themselves often need a lot of support.
\end{abstract}

Keywords: migrant background, student, education system, Lithuania.

\section{Introduction}

The large-scale migration is a recent phenomenon, not only in countries with a long history of immigration (e.g. United States, Australia), but also in European countries (Buchmann \& Parrado, 2006). The new wave of migration causes the changes in country policies in economy, social system, education, etc. In the context of the occurring migration processes, the educational system plays a significant role. As Buchmann \& Parrado (2006) note, "key adaptation outcomes and prospects for social mobility largely stem from their experiences in the educational system" (p. 345). Hence, educational achievement is an important predictor for integration into the host society. Scientific (Buchmann \& Parrado, 2006; Jacobs, 2013) and international studies on students' achievements (e.g. OECD PISA, 2016) demonstrate that the achievements of students with 
migrant backgrounds differ from the ones of students having status like this. According to OECD PISA 2015, the background of their integration is inclusive education (Faas, Sokolowska, \& Darmody, 2015). Inclusive education tends to include a safe and supportive (academic and social) environment; shared leadership; family involvement; as well as a supportive network of professionals. Such a system of inclusive education facilitates academic and social integration, which is especially important when considering students with a migrant background (Faas, Sokolowska, \& Darmody, 2015).

Although different countries encounter similar challenges and problems when integrating students with migrant backgrounds, there exist certain differences among them. For instance, the study of Buchmann \& Parrado (2006) reveals that "the lower achievement of immigrant students can be largely explained by differences in family background and language proficiency in the United States, as well as in some other societies with a long history and tradition of immigration, these factors do not explain the sizable gap in performance between immigrant-origin and native born students in many Northern European societies" (p. 365). In other words, the experience, history and geographical position of a country determine the differences in the process of integration.

Hence, the research question of the study is: How are students with a migrant background integrated into the education system in Lithuania? Moreover, what main possibilities and problems does the system face throughout their integration process?

First, we will provide a review of the recent perspectives of integration in the education system of students with a migrant background. Next, we will focus on the current study methodology and its main results. Finally, we will highlight the future research directions concerning issues on the integration of students with a migrant background into the education system.

\section{Literature review}

\section{Strategies for successful integration of students with a migrant background}

There is no common definition of who a 'migrant' is (Katsarova, 2016), or a common agreement among different countries and/or organisations (Global Education Monitoring Report, 2019). In the present article, we follow the conception of Eurydice (2019) that 'students with a migrant background' or 'a migrant student' are the newly arrived/first generation, second generation or returning migrant children.

Recent migration processes and the increasing refugee issues in Europe have led to an increasing number of countries analysing the experiences of such children in the education system. Countries with experience in migration 
processes better meet the needs of current migrants, including the educational needs of refugees (Koehler \& Schneider, 2019). In the latest Eurydice report (2019) on integration of migrant students in education in 42 education systems (in $28 \mathrm{EU}$ member states), it is emphasised that although these children have access to education, there are many disadvantages. For instance, too little attention is paid to students' social and emotional needs. In addition, countries mainly focus on the language of instruction. Meanwhile, little attention is paid to the individual progress of a child, as well as too little support is provided for teachers and school heads (e.g. providing teaching assistants).

Recent studies (Eurydice, 2019; Koehler \& Schneider, 2019; Ismail, 2019) suggests that European countries (e.g. Germany, Austria, Finland, Sweden) have good strategies for integrating migrant students in education. For instance, Ireland supports migrant students by enabling them to sit the Leaving Certificate (the final exam, which gives access to higher education) in $15 \mathrm{EU}$ languages and provides support programmes for underachieving students (including migrant students) (Faas, Sokolowska, \& Darmody, 2015). In the UK, peer education and mentoring programmes (Manzoni \& Rolfe, 2019) are widely applied as pedagogical techniques and teaching/learning strategies (e.g. The Buddy scheme) and serve their purpose well while integrating migrant students.

Ismail's (2019) study on the position of Somali immigrants in Finland demonstrates that "equal resources are not enough to solve the problem" (p. 731). The author notes that parent involvement in school life and their language skills improvement are the ways to help their children to successfully integrate in education. Another important aspect is that the Government of Finland approved a new integration programme in 2016, which combines social, educational and economic spheres. Top-level strategies for integrating migrant students into schools also exist in the afore-mentioned EU countries, such as Germany and Ireland (Eurydice, 2019).

Jacobs (2013) maintains that sending society actors in destination countries or diaspora schools can be employed to assure successful integration. Although the author recognises that the sending society actors seem to have only a limited impact on the educational integration of migrant children, he claims that country experiences prove the importance of transnational integration dimension (e.g. bilateral agreements on migrant education about the language and culture of the country of origin) for integration.

The practice of different countries regarding immigrant student immersion or separation processes (being taught in separated welcome or reception classes to acquire certain levels of the host country language) is ambiguous. As Koehler and Schneider (2019) note that the separation process would primarily occur in Germany, while immersion would be given preference in Sweden. The authors claim that the importance of preparing a child for immersion cannot be denied, 
yet most importantly, the separation time should be reduced as much as possible taking into account the age of the children and other circumstances.

Despite the different practices prevalent in European countries regarding the integration of migrant students in education, the political dimension is recognised as significant. Among such important aspects, it would be important to focus on the social context and its influence on integration (Ismail, 2019); commonality and cooperation of governmental and school policies (Schachner et al., 2017), which must be combined with regular state funding for education, appropriate training of professionals working in a multicultural environment, as well as assistance for education staff and school heads.

\section{The context}

Exploring the integration process of students with a migrant background in the Lithuanian context is important for a number of reasons. Firstly, Lithuania as a state has no deep migration traditions. Since 2017, increased numbers of migrant students in Lithuanian schools makes Lithuania an interesting case study. Besides, in the case of Lithuania, the majority of students with a migrant background are children aged 15 and having Lithuanian citizenship (Švietimo paslaugu sugrįžusiems asmenims poreikio savivaldybèse tyrimas, 2018). Secondly, according to the Migrant Integration Policy Index (2014), Lithuania ranks 34 out of 38 among the countries, where migrant integration policy is viewed as unfavourable. Among other fields, the field of education is seen as critically unfavourable. Thirdly, Lithuania has no strategy for integrating migrants into education. So far, Lithuania has been developing its policy on the integration of migrants.

In the Republic of Lithuania, participation in full-time education is compulsory until the age of 16 . That means that the vast majority of migrant students from the younger generation should attend school and the State must guarantee their right to education. Lithuania has taken a number of actions and initiatives in the field of education in recent years to ensure access to education. For example, the Ministry of Education, Science and Sports has developed and provided guidance in the areas of returnee admission, needs identification, education, assessment, additional funding, teacher qualification development, information and counselling since 2019. Simultaneously, the Ministry has initiated the establishment of a school network (including 21 schools) in 10 Lithuanian Municipalities. One of the purposes of this network is to advise other educational institutions on successful experiences and practices in integrating migrant students.

We would like to draw the readers' attention to a number of guidelines and recommendations for the integration of migrant children, which we consider to be 
ambiguous. For instance, the Recommendation of the Ministry of Education, Science and Sports (2019) underlines that additional funding shall be granted for schools and teachers working with migrant students provided the returnee student is a citizen of the Republic of Lithuania. A possibility to have equalising classes/groups in the school is provided, yet such classes/groups are organised only when a group of at least 10 students is formed. According to our researchers, such and similar guidelines increase exclusion rather than facilitate the integration of all students with a migrant background. Despite that fact, it is commendable that the issue of the integration of students with a migrant background becomes a subject of educational policy and public discourse.

\section{Methodology}

A qualitative approach was selected to attain the aim of the research - to reveal the teachers' attitude of teachers towards the integration process of students with a migrant background, as well as the incurred problems and ways of their solution. The sample for the study was constructed by a non-random sampling method. The latter sample allowed the study to identify individuals who were easy to find and access (Best \& Kahn, 2006). The sample size consisted of 12 informants. All the informants were teachers of Lithuanian progymnasiums. All the participants were women, with aged 41 on average and having 21.3 years of professional experience. The study participants had 1-3 students that could be assigned to a migrant group in their teaching practice. The method employed was a semi-structured interview.

The study was performed in August-December 2019. The interview process was conducted in accordance with the basic ethical principles. Participation in the interview was based on the volunteering principle, the teachers took part in the study without having been coerced and deceived. The interview was anonymous, ensuring the confidentiality of the participants. These principles helped to ensure the reliability and objectivity of the collected data.

The following themes were important for the analysis of the scientific problem:

(1) what are the main problems (educational, social, psychological) that teachers face when dealing with the children of expatriates and foreigners;

(2) what integration measures are applied at school;

(3) what is the nature of the assistance provided by parents, colleagues and municipalities for returning expatriates or incoming children when it comes to integrating returning expatriates and expatriate children; 
(4) what political and administrative decisions (in the opinion of the study participants) would ensure the success of education and social integration of expatriate and incoming children.

Qualitative content analysis (Krippendorff, 2004) was used for data analysis. In researching the scientific problem, participants' authentic statements were collected, coded and analysed, distinguishing between categories and subcategories, looking for authentic linguistic expressions and language fragments, as well as justifying the categories and sub-categories for relevance and meaningfulness.

\section{Research results}

The analysis of the research data revealed three groups of categories:

(1) problems and difficulties in the successful integration of migrant children;

(2) the necessary and essential means for this integration;

(3) and political and administrative decisions necessary for successful integration. Below we present the results of the study for each category separately.

As far as the problems and difficulties were concerned, the participants of the study focused on language and knowledge gaps and their non-compliance with Lithuanian standards, cultural differences, and lack of teaching/learning resources (Table 1).

Table 1 Problems and difficulties in educating migrant students

\begin{tabular}{|c|c|c|}
\hline Category & Sub-category & $\begin{array}{l}\text { Fragments of the authentic statements of the research } \\
\text { participants }\end{array}$ \\
\hline \multirow{2}{*}{$\begin{array}{l}\text { Problems } \\
\text { and } \\
\text { difficulties } \\
\text { in educating } \\
\text { migrant } \\
\text { students }\end{array}$} & $\begin{array}{l}\text { Lack of knowledge } \\
\text { of the curriculum, } \\
\text { especially the } \\
\text { Lithuanian language }\end{array}$ & $\begin{array}{l}<\ldots>\text { The problems were mainly caused by the } \\
\text { Lithuanian language because the programme was } \\
\text { too difficult according to their skills, and the text } \\
\text { interpretations were difficult (I 1); } \\
<\ldots>\text { English is excellent and Lithuanian is quite } \\
\text { poor (I 9); }\end{array}$ \\
\hline & Knowledge gaps & $\begin{array}{l}<\ldots>\text { such students learn according to an individual } \\
\text { plan }<\ldots . .>\text { the knowledge of the subjects of the } \\
\text { incoming students is very different from that of our } \\
\text { students, they feel the gaps in the subjects of history } \\
\text { and geography (I 3); } \\
\text { It was not easy for someone, who could not speak the } \\
\text { language, to speak about history, I was looking for } \\
\text { films (I 12); }\end{array}$ \\
\hline
\end{tabular}




\begin{tabular}{|c|c|}
\hline $\begin{array}{l}\text { The need for } \\
\text { educational materials } \\
\text { written in the } \\
\text { language that has } \\
\text { been used before }\end{array}$ & $\begin{array}{l}\text { There was a student from Sweden, we were looking } \\
\text { for someone who could help get the learning } \\
\text { materials (I 5); } \\
\text { We use gestures and look for films in the language } \\
\text { they understand (I 11); }\end{array}$ \\
\hline $\begin{array}{c}\text { Extra preparation for } \\
\text { lessons }\end{array}$ & $\begin{array}{l}\text { More time is needed to prepare for lessons, and } \\
\text { sometimes it is difficult to communicate (I 2); } \\
\text { I gave more visual material, all kinds of activities, } \\
\text { until he learned some Lithuanian (I 7); } \\
\text { There's a lot of preparation to look for different } \\
\text { sources and materials (I 12); }\end{array}$ \\
\hline Cultural differences & $\begin{array}{l}<\ldots>\text { a different culture, completely different } \\
\text { learning experience, rules, (I 5); } \\
<\ldots>\text { he felt very free in the classroom, sometimes } \\
\text { the kids laughed, which was disturbing (to the } \\
\text { student) (researcher's note) (I 8); } \\
\text { It was not easy for the student, she was Lithuanian, } \\
\text { but she did not speak Lithuanian, and yet she was not } \\
\text { a British citizen (I 9). }\end{array}$ \\
\hline
\end{tabular}

Highlighting the problems and difficulties, the participants noted that language skills made it difficult for peer adaptation and understanding of educational strategies. Not only linguistic, but also cultural differences were identified as significant. The teachers claimed they lacked methodological materials and textbooks to teach children, whose mother tongue was not Lithuanian, as well as missed opportunities to learn about other teachers' methods and exchange knowledge and experience. To overcome these difficulties and emerging problems, the teachers took various measures to ensure student integration (Table 2).

Table 2 Measures applied to ensure the integration of migrants in the educational process

\begin{tabular}{|c|c|l|}
\hline Category & Sub-category & $\begin{array}{l}\text { Fragments of the authentic statements of the research } \\
\text { participants }\end{array}$ \\
\hline $\begin{array}{c}\text { Measures to } \\
\text { ensure } \\
\text { integration }\end{array}$ & $\begin{array}{c}\text { Individual learning } \\
\text { planning of } \\
\text { education }\end{array}$ & $\begin{array}{l}\text { I remember a case where we had a student who was } \\
\text { only able to learn only when I worked individually } \\
\text { with him, }<. .>\text {, then we found a friend for him and } \\
\text { taught them together (I 8); } \\
<\ldots>\text { teachers have adapted their tasks creatively, } \\
\text { slowing down their learning pace so that they could } \\
\text { adapt to the student (I 1); } \\
\text { I would distinguish individual learning, but } \\
\text { individual work of a teacher is still required (I 2); }\end{array}$ \\
\hline
\end{tabular}




\begin{tabular}{|c|c|}
\hline & $\begin{array}{l}\text { We try that they do their homework in the classroom } \\
\text { and work with them individually longer (I 11); }\end{array}$ \\
\hline $\begin{array}{l}\text { Non-formal } \\
\text { education }\end{array}$ & $\begin{array}{l}\text { We offer informal activities: there is a dance group, } \\
\text { nature lovers' club, so we direct them to the activities } \\
\text { that might be interesting (I 3); } \\
\text { The best integration is through activities, tours, } \\
\text { museums, and active tasks. They include traditions, } \\
\text { culture and communication (I 12); } \\
\text { We try to help them adapt to the school community, } \\
\text { understand the rules, attend all events, and feel good } \\
\text { (I 5); }\end{array}$ \\
\hline Additional education & $\begin{array}{l}<\ldots>\text { we provide additional education, we discuss it } \\
\text { with several teachers and set lower goals (...) (I 10); } \\
\text { We provide counselling, not necessarily by the same } \\
\text { teacher (I 11); } \\
\text { We plan additional lessons and time to bridge the } \\
\text { knowledge gaps (I 5). }\end{array}$ \\
\hline
\end{tabular}

Thus, the results of the research revealed that additional consultations on the Lithuanian language and other subjects were provided in order to ensure purposeful integration into the educational process. Subject lessons were personalised, addressed specific challenges experienced by the child and reduced the learning gaps. In order to strengthen the integration processes, the students were involved in non-formal education activities. The benefit of non-formal education was emphasised in expanding the students' vocabulary and communication skills, as well as their knowledge of traditions. Another important component of integration considered by the informants was the involvement of students and their families in school activities: "The children who came to us were very easily and quickly integrated into the school community" (I 6); "It depends on the child, one can feel great at school and the other needs extra support again and again <...>" (I 12); "We talk a lot with the students and their parents about how they are doing, what is difficult <...>” (I 4). The research participants unequivocally appreciated the employed means and their effectiveness: "we tried to appoint students-friends for them, the children do not want to communicate, there is a gap" (I 4). While in other countries (as mentioned in the theoretical part of this article), the Buddy scheme is merely used as an effective means of integrating such students.

The most commonly used measures for successful integration of students fell on the shoulders of the teacher. The teachers devoted extra time for preparing assignments, preparing for consultations, as well as searching for and adapting methodological and educational materials. The data clearly identify the teachers' efforts to change the existing situation and involve students in the educational process, yet it is noteworthy that they needed external support in the process. The 
vast majority of the informants pointed out that the successful integration of children required parents' involvement and collaboration with the school: "this is how [the teacher and parents] work together for the child" (I 9); "Parents cooperate well, coordinate learning with teachers, help children with tasks, and work in addition to help learn Lithuanian" (I 2). However, such a cooperation was not always established: "parents did very little work with the child, full responsibility was given to the school, and such cooperation would be necessary" (I 5). The teachers also pointed out that they needed support from other professionals: "a teaching assistant would be good ..." (I 12); "the help of an assistant teacher is needed immediately, but it is necessary to obtain the decision from pedagogical-psychological service, which takes too long ...” (I 4). In other words, according to the informants, they did not receive sufficient support and assistance from other professionals to ensure successful integration of the students. The informants pointed out that successful integration also required certain processes at school administration and/or national level (Table 3).

Table 3 Political and administrative decisions that support integration

\begin{tabular}{|c|c|c|}
\hline Category & Sub-category & $\begin{array}{c}\text { Fragments of the authentic statements of the research } \\
\text { participants }\end{array}$ \\
\hline \multirow[t]{2}{*}{$\begin{array}{l}\text { The nature of } \\
\text { political and } \\
\text { administrative } \\
\text { decisions }\end{array}$} & $\begin{array}{l}\text { The need for } \\
\text { solutions at the } \\
\text { national level }\end{array}$ & $\begin{array}{l}\text { The pupil basket for such children could be larger } \\
\text { (similar to that of children with special educational } \\
\text { needs). These students could then be assigned teaching } \\
\text { assistants or extra hours to compensate for the } \\
\text { learning difficulties (I 2); } \\
\text { I think there could be more methodological materials } \\
\text { developed to work on specific topics with such } \\
\text { students, and these methodological materials could be } \\
\text { provided in a number of languages (I 4); } \\
\text { The teachers would need materials, which could be in } \\
\text { the electronic format, to work with non-Lithuanian } \\
\text { speakers (I 3); } \\
<. . .>\text { we lack focused courses for teachers explaining } \\
\text { how to work with migrant students (I 6); }\end{array}$ \\
\hline & $\begin{array}{l}\text { Support from } \\
\text { the staff of } \\
\text { municipal } \\
\text { education } \\
\text { departments }\end{array}$ & $\begin{array}{l}\text { We have not asked for help from the municipality, we } \\
\text { try to do our best, we discuss the issues with each } \\
\text { other, I call my colleagues (I 5); } \\
\text { The municipality will not be very helpful here, maybe } \\
\text { it could spare some additional funding } \\
\text { (I 3); } \\
<\ldots \text {.. > we approached the education department when it } \\
\text { came to solving a complex problem, there was a } \\
\text { difficult situation with the whole family }<\text {...>, } \\
\text { unemployed parents, so a social pedagogue was } \\
\text { involved (I 11); }\end{array}$ \\
\hline
\end{tabular}




\begin{tabular}{|c|l|l|}
\hline & $\begin{array}{l}\text { There is not much to help for we need to work with the } \\
\text { student ourselves (I 8); }\end{array}$ \\
\cline { 2 - 3 } & $\begin{array}{l}\text { We always communicate with each other <... > looking } \\
\text { for help, we had a case where we asked for help from } \\
\text { administrative } \\
\text { and collegiate } \\
\text { decisions }\end{array}$ & $\begin{array}{l}\text { VMU, the teachers gave me some materials (I 6); } \\
\text { We solve problems collegially, we know the cases of } \\
\text { our students (best I 4); } \\
\text { When I had such a student, the principal took a keen } \\
\text { interest in the situation, and we looked for } \\
\text { methodological materials together (I 10). }\end{array}$ \\
\hline
\end{tabular}

The educators, who participated in the research, expressed the need to receive more obvious and purposeful systematic assistance, both financial and methodological, in working with the incoming students. Targeted methodological materials, including methodological tools and electronic resources for non-native children, were considered to be an important support for successful integration. The need for targeted qualification development courses was expressed. The participants of the research did not express high expectations regarding the cooperation with municipal representatives in solving the problems of education and integration of incoming students. It was noted that more obvious municipal assistance was possible when the problem was complex and necessary for the whole family. In the opinion of the study participants, the most meaningful help could be obtained from the school community through collegial communication and cooperation, as well as sharing of experience and support from school heads.

\section{Conclusions and discussion}

The research presented in this paper focuses on successful integration of migrant students in education. The recently performed studies (Eurydice, 2019) reveal that European countries have developed good strategies for successful integration of students with a migrant background. This present study confirms that Lithuania does not have a long history in migration processes. In the light of this, it is interesting to analyse how Lithuania deals with migrant students' integration in education.

It has been found that the documents of Lithuanian education policy regulate and provide recommendations on strengthening the integration of migrant students. However, the existing practices raise considerable debates regarding their effectiveness and affordability. As has been proved by our study, various measures are applied to ensure the integration of migrant children: individual education plans, non-formal education activities, individual teaching of the Lithuanian language, and the Buddy support model. Most of the teachers involved in the study face a lack of methodological materials and tools to assess and meet 
the individual educational needs of returning children of different ages. It also recognises the lack of adequately trained teachers who can work with children with diverse linguistic and cultural backgrounds. In order to compensate for the lack of methodological aids, the teachers organise education for children who have returned or come from abroad relying on their own experience and that of their colleagues, strengthening their relations with parents and social partners. School administrators and teachers are often in search of the most optimal and personalised solution for the integration process, and there is no obvious practice to contact municipal education departments. The participating teachers express their expectations for a more active and meaningful involvement of parents in their children's education and integration.

This research contributes to the existing body of knowledge in a variety of ways. Firstly, the history, traditions and other cultural and institutional aspects of the country are important in ensuring migrants' integration. The results of our study confirm the conclusion of Buchmann and Parrad, made in 2006, that institutional aspects of a host society matter for successful migrant adaptation. Moreover, we cannot expect that the countries having no previous experience of migration processes or are encountering them right now, will be able to deal with integration issues immediately (Koehler \& Schneider, 2019). Secondly, the experience of advanced countries, such as Finland and Sweden (Ismail, 2019; Koehler \& Schneider, 2019), shows that all areas of the society need to be brought together to ensure successful integration of migrants. In other words, the issue of migration will be successful when social, educational, economic and other sectors consider this as a priority for their area. Thirdly, while teachers in different countries face similar challenges, different countries have different strategies for student integration.

There are some limitations and future directions of this study. The main limitation of this study is that the research sample includes only one educational sector, i.e. the teachers of progymnasiums. We understand that the issue of migrant student integration is multifaceted, so this study reveals only a part of the research phenomenon. The fruitful line of the research in the Lithuanian context could be a mixed method longitudinal research. Further studies could include a case study of a school.

\section{References}

Best, J.W., \& Kahn, J.V. (2006). Research in Education. 10th Edition. USA: Pearson Education.

Buchmann, C., \& Parrado, E. (2006). Educational achievement of immigrant-origin and native students: A comparative analysis informed by institutional theory. International Perspectives on Education and Society, 7, 345-377. DOI: http://dx.doi.org/ 10.1016/S1479-3679(06)07014-9 
ŠMSM rekomendacijos Dèl sugrịžtančiu ị lietuva asmenu švietimo ir integracijos. (2019).

Faas, D., Sokolowska, B., \& Darmody, M. (2015). Everybody is Available to Them’: Support Measures for Migrant Students in Irish Secondary Schools. British Journal of Educational Studies, 63(4), 447-466. DOI: http://dx.doi.org/10.1080/00071005. 2015.1049974

Integrating Students from Migrant background into Schools in Europe: National policies and Measures. (2019). Eurydice Report. Brussels.

Ismail, A.A. (2019). Immigrant Children, Educational Performance and Public Policy: a Capability Approach. Journal of International Migration and Integration, 20, 717-734.

Jacobs, D. (2013). The Educational Integration of Migrants. What is the Role of Sending Society Actors and is there a Transnational Educational Field? INTERACT Research Report. Italy: European university Institute.

Katsarova, I. (2016). Integration of migrants: The education dimension. Briefing. European Parliament: European Parliamentary Research Service.

Koehler, C., \& Schneider, J. (2019). Young refugees in education: the particular challenges of school systems in Europe. Comparative Migration Studies, 7(28), 1-20.

Krippendorff, K. (2004). Content Analysis: an Introduction to Its Methodology. 2nd Edition. London: Sage Publications.

Manzoni, C., \& Rolfe, H. (2019). How schools are integrating new migrant pupils and their families. London: National Institute of Economic and Social Research.

Migrant integration policy index. (2014). Retrieved from http://www.mipex.eu/

OECD. (2016). PISA 2015 Results (Volume I): Excellence and Equity in Education, PISA, OECD Publishing, Paris. DOI: http://dx.doi.org/10.1787/9789264266490-en

Schachner, M.K., He, J., Heizmann, B., \& Van de Vijver, F.J.R. (2017). Acculturation and School Adjustment of Immigrant Youth in Six European Countries: Findings from the Programme for International Student Assessment (PISA). Frontiers in Psychology, 8, 649. DOI: https://doi.org/10.3389/fpsyg.2017.00649

Švietimo paslaugu sugrižusiems asmenims poreikio savivaldybèse tyrimas. (2018). Vilnius: PPMI.

Williams, F.C., \& Butler, S.K. (2003). Concerns of Newly Arrived Immigrant Students: Implications for School Counselors. Professional School Counseling, 7(1), 9-14. 